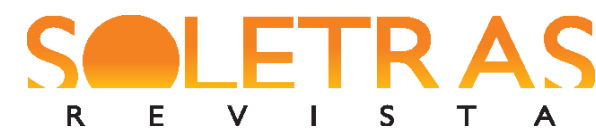

\section{Ancestralidade negro-brasileira no romance Ponciá Vicêncio, de Conceição} Evaristo
Ricardo Oliveira de Freiras ${ }^{1}$

Sandra Andrade dos Santos ${ }^{2}$

Resumo: Investigamos o modo com que a ancestralidade negro-brasileira vai se apresentar como elemento constitutivo na narrativa de Conceição Evaristo, através da análise do romance de sua autoria, Ponciá Vicêncio (2003). Reconhecendo a densidade literária da autora, exploramos a construção da personagem Ponciá Vicêncio, apresentando elementos identificadores do que defendemos como sendo um conjunto de traços de ancestralidade presentes na obra. Relacionamos esses elementos às categorias de memória e silêncio. Apoiados no romance Ponciá Vicêncio, analisamos os modos e formas com que Conceição Evaristo, através do artifício da escrevivência (a escrita do cotidiano, da memória da sua vida e do seu povo). Com isso, revelamos a experiência de ser mulher negra numa sociedade pós-abolicionista, que, sem abrir mão do caráter poético, utiliza como dispositivos aspectos da ancestralidade negro-brasileira com grande aporte da memória, de uma memória ancestral negro-brasileira.

Palavras-chave: Literatura negro-brasileira. Ancestralidade. Memória. Conceição Evaristo.

\title{
Entrada
}

A cultura e a arte produzidas por sujeitos, grupos e comunidades à margem das histórias oficiais da cultura, que, nos últimos anos tem tomado corpo, não somente como objeto de produção, (produto), mas, também, como objeto de análise (investigação), têm assumido importante papel junto aos fluxos de combate às culturas hegemônicas, já que têm funcionado como importantes instrumentos de resistência, num tipo de manifestação cultural e artística aliada às causas dos movimentos sociais, o dito ativismo. A produção literária da e sobre a periferia, sobre os juridicamente minoritários, sobre comunidades subalternizadas e desprestigiadas tem assumido importante papel ao contrapor modelos de pensamento canônicos, forças hegemônicas e, combativamente, atribuir novos sentidos políticos às causas, aos problemas e às prioridades das comunidades no contexto do neoliberalismo. A produção literária, nesse sentido, tem apresentado novas propostas e importantes mudanças estruturais acerca da criação, da distribuição e do consumo, que, como lembra Heloísa Buarque de

\footnotetext{
${ }^{1}$ Doutorado em Comunicação e Cultura na Universidade Federal do Rio de Janeiro (UFRJ). Professor Titular da Universidade do Estado da Bahia (UNEB). Professor Colaborador do Programa de Pós-Graduação em Letras, Linguagens e Representações da UESC. Professor Permanente do Programa de Pós-Graduação em Estudos das Linguagens (PPGEL/UNEB), Salvador, Bahia, Brasil. E-mail: ricofrei@gmail.com

${ }^{2}$ Mestrando no Programa de Pós-Graduação em Estudos de Linguagem (PPGEL/UNEB), Salvador, Bahia, Brasil. E-mail: sandra.andrade.s@gmail.com
} 


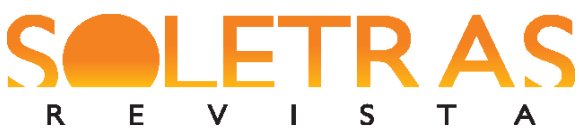

Hollanda, faz com que "a própria noção de cultura, e por tabela a de literatura, seja forçada a repensar seus parâmetros e até mesmo, o que é mais interessante, sua função social" (HOLLANDA, 2017).

A obra de Conceição Evaristo não foge à regra. É literatura que tenta, como diz a própria Evaristo, sublimar a realidade, num sinal claro de que é produção para satisfazer os interesses da autora. Mas é, também, literatura feita para a comunidade, para fortalecer a comunidade de brasileiros descendentes de africanos, brasileiros negros, que, aqui, denominaremos como sendo integrantes de uma cultura negro-brasileira. Afinal, como lembra a própria autora: "A questão negra não é uma questão para o negro resolver, a questão indígena não é para o índio resolver. São questões para todos os brasileiros pensarem" (EVARISTO, 2016).

Desse modo, iniciamos nossa viagem pela análise da obra de Conceição Evaristo lançando questões. Em alguma medida seríamos capazes de apartarmo-nos do que nos antecede; de quem nos antecede; apartarmo-nos de tudo que é etéreo e sempre esteve antes, durante e depois de nós? No continente africano, com toda a diversidade étnica e cultural ali presentes, essa preposição seria facilmente respondida. Não conseguiríamos, já que as culturas africanas negras, na sua quase totalidade, vivem e se organizam através da reverência a seus ancestrais, com base nas mais variadas formas de cultos religiosos. No Brasil, entretanto, a resposta merece atenção. Afinal, pensar sobre o conceito de ancestralidade negro-brasileira na contemporaneidade é, antes de tudo, ter a consciência de que o conceito de ancestralidade, aqui, ganha um corpo totalmente novo.

Anteriormente tida como uma categoria que tratava as relações de consanguinidade, a ancestralidade começa a ser pensada como uma categoria analítica - sobretudo, nas últimas três décadas, com a emergência dos Estudos Pós-Coloniais, que possibilitariam pensar o debate acerca das tradições negro-africanas como gerador de uma importante série de estudos de ordem epistemológica e política, ao apresentar como base as experiências dos povos negroafricanos recriadas em solo brasileiro.

Adilbênia Machado diz que a ancestralidade é:

[...] uma raiz sentimental, que recria, atualizando-se na universalidade, a partir de um contexto, manifestando-se nos costumes e tradições, com grande aporte na memória grupal e individual, suas manifestações materiais 


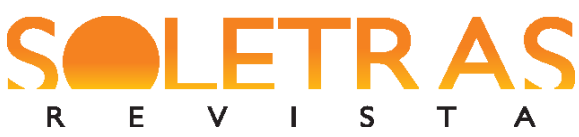

e imateriais, especialmente no seu fortalecimento pela identidade e preservação, integração, sua cultura (MACHADO, 2014, p. 6).

A ancestralidade aparece, aqui, extremamente relacionada às questões da identidade, aos modos de construção da identidade, da constituição do ser negro brasileiro.

$\mathrm{Na}$ experiência da tradição, a ancestralidade nos impulsiona a pensar sobre muitos mundos, reconstruir nossas identidades, ser potência criativa e força motora.

Refletir sobre a ancestralidade no Brasil é refazer caminhos de esquecimentos e omissões, e na contemporaneidade é refazer caminhos de resistência e ressignificações. Eduardo Oliveira afirma que as culturas africanas e afro-brasileiras "foram relegadas ao campo do folclore com propósito de confiná-las ao conjunto de representações estereotipadas, via de regra, alheias ao contexto que produziu essa cultura" (OLIVEIRA, 2007, p. 1). O processo de folclorização, ao qual o autor se refere, constitui uma forma de dominação efetiva, retirando do sujeito a sua possibilidade de produzir significados da e sobre a sua própria cultura, num tipo de assujeitamento, que impõe sobre o indivíduo assujeitado normas e regras de comportamento, visões de mundo e estilos de vida por ele desconhecidos. $\mathrm{Na}$ contemporaneidade, com o advento do fortalecimento dos projetos promotores de iniciativas inclusivas, democráticas, contra-hegemônicas, alternativas a modos convencionais de produção de cultura e de expressões em arte, cada vez mais, deparamo-nos com ações ressiginificadas, que podem ser mais ou menos autônomas, em relação à criação de significados, mais ou menos desterritorializadas, em relação aos seus lugares de fala, de acordo com o contexto em que surgem e se multiplicam e com os seus interesses, problemas, prioridades e causas.

Nesse sentido, a emergência de produção literária que promove a valorização a pertencimentos étnicos, locais, regionais e culturais, concretizada pela expressiva proliferação de saraus; pelo surgimento de mais e mais escritores que falam da periferia; pelo mercado editorial alternativo, artesanal, marginal; pelo surgimento de bibliotecas comunitárias, de bibliotecas móveis; pelo uso da Internet como recurso para produção e distribuição de textos; pela emergência dos movimentos sociais; por tudo isso, contribui radical e positivamente para a consolidação de um novo nicho literário que, quando não forma escritores ativos, não passivos, forma, minimamente, leitores conscientes. A consolidação de uma vertente literária negro-brasileira é resultado das transformações que assolaram o Brasil e o mundo em desenvolvimento nas últimas décadas. Essas transformações não foram uma particularidade 
do caso brasileiro, mas, de modo geral, das periferias globais que impuseram uma nova lógica de ver e pensar a produção literária e, por extensão, a hegemonia de mercado, através de ações de ativismo cultural e artístico, que fez do caso latino-americano um réplica do caso das periferias dos grandes centros urbanos brasileiros.

A história narrada em Ponciá Vicêncio, por exemplo, nos remete à realidade de milhares de mulheres negras brasileiras que foram deslocadas de seus lugares de origem, de suas famílias e da sua cultura em nome de um projeto produzido pela elite sócio-política brasileira, um projeto de desenvolvimento nacionalista com fortes bases em traços de europeidade que, por sua vez, sustentavam a perseguição a um modelo de civilidade (elitizada) como vista na Europa. Mulheres negras nunca estiveram incluídas no projeto burguês, elitista e embranquecido de Estado. Essa não é somente uma realidade brasileira, mas, uma realidade de muitas outras nações em desenvolvimento que utilizaram mão de obra de escravizados como força de trabalho durante o período colonial. É nisso que os estudos interessados nas estratégias pós-coloniais e decoloniais promovem o encontro entre diversas nações marcadas pela escravização do lado de cá do Atlântico.

No Brasil do século XXI, a literatura negro-brasileira, ao ganhar força no mercado literário, vai constituir novos significados sobre os elementos da cultura e da religiosidade negro-brasileiras, situando o negro no centro das suas narrativas, identificando-o como o sujeito principal da história, como protagonista, e abrindo espaço para as vozes negras femininas, gritadas por autoras, leitoras, militantes, produtoras e espectadoras ativas.

Com uma narrativa repleta de lembranças e simbologias da religiosidade negrobrasileira, Conceição Evaristo busca afirmar seu lugar na literatura contemporânea. Numa entrevista concedida a um jornal impresso ${ }^{3}$, a autora fala da construção estética de sua escrita, que marca, não apenas uma crítica social forte, mas, também, aspectos ancestrais da cultura e religiosidade negro-brasileiras:

Eu sempre tenho dito que a minha condição de mulher negra marca a minha escrita, de forma consciente inclusive. Faço opção por esses temas, por escrever dessa forma. Isso me marca como cidadã e me marca como escritora também (EVARISTO, 2017).

\footnotetext{
${ }^{3}$ Conceição Evaristo: a literatura como arte da "escrevivência". Jornal O Globo. Entrevista concedida a Leonardo Cazes. Disponível em: <http://oglobo.globo.com/cultura/livros/conceicao-evaristo-literatura-comoarte-da- escrevivencia-19682928>. Acesso em: 05/10/2016.
} 
O conceito de escrevivência, que marca a obra da escritora, traduz-se pelo ato de reescrever o cotidiano, ressignificar as experiências, as dores, retirar o velcro do silêncio contido nas histórias que ouviu ao longo da vida, suplementando e rasurando a história e o cânone da literatura brasileira.

Doutora em Literatura Comparada pela Universidade Federal Fluminense e Mestra em Literatura Brasileira pela Pontifícia Universidade Católica do Rio de Janeiro, Maria Conceição Evaristo de Brito nasceu na favela do Pindura Saia, em Belo Horizonte. Foi empregada doméstica até concluir o Curso Normal aos vinte e cinco anos. Inspirou-se em figuras como Carolina Maria de Jesus para sentir-se autorizada a "escreviver" suas experiências e as histórias que ouvia ao longo do caminho. Sua escrita é a voz de uma geração de mulheres negras da sua família. Ela fala do silêncio e da perpetuação da condição de escravização, seja nos porões dos navios, seja nas trouxas de roupas sujas dos brancos.

Antecedida por personalidades como Maria Firmina dos Reis, nossa primeira romancista negra brasileira, autora do romance Úrsula, publicado em 1859, e caminhando lado a lado com a comunidade feminina de escritoras, composta por nomes como Alzira Rufino, Geni Guimarães, Miriam Alves, Esmeralda Ribeiro e Lia Vieira, Conceição Evaristo é, na contemporaneidade, a maior representação do grupo de mulheres negras escritoras. Alcança, em 2017, o apogeu da visibilidade midiática, marcando presença constante nos principais eventos literários do país.

Numa outra entrevista concedida a um outro jornal impresso ${ }^{4}$, Conceição Evaristo afirma ter consciência de que o atraso no reconhecimento da sua obra deve-se a questões sociais: "Esse desconhecimento, que muitas vezes eu sou vítima, de modo geral é o desconhecimento que é reservado às mulheres negras. Estamos no processo de luta de afirmação da nossa visibilidade" (EVARISTO, 2017). Para Evaristo, é importante pensar o lugar que ela ocupa na literatura brasileira hoje como uma forma de negar a meritocracia. Como diz na entrevista dada ao jornal baiano:

Eu fico muito feliz e quero que essa visibilidade que eu estou tendo agora sirva de reflexão para as pessoas pensarem em conhecer outras mulheres

${ }^{4}$ Literatura potente de Conceição Evaristo é tema de mesa da FliCaixa. Jornal Correio. Entrevista concedida a Marília Moreira. Disponível em: <http://www.correio24horas.com.br/noticia/nid/literatura-potente-deconceicao-evaristo-e- tema-de-mesa-da-flicaixa/>. Acesso em: 18/09/2017. 
negras que também escrevem, também produzem. As exceções criam a ilusão de que se todo mundo trabalhar consegue. Eu conheço muitas pessoas que trabalham e que não conseguem. As exceções (incluindo aí a de uma escritora negra) servem justamente para explicitar que há algo errado na realidade brasileira. As exceções têm de valer para pensar a regra (EVARISTO, 2017).

O sucesso tardio vivenciado pela escritora, que chega somente após ter completado setenta anos, legitima sua fala. Como bem lembra Stelamaris Coser (2015), a notoriedade que Conceição Evaristo possui, especialmente fora do Brasil, é crescente desde o ano de 1988, Conta coma tradução de alguns dos seus livros e a inclusão da sua obra antologias alemãs sobre literatura afro-brasileira ${ }^{5}$. Atualmente, Evaristo é considerada uma das escritoras negras mais pesquisadas e influentes da atualidade, e seu nome tem sido reconhecido e aguardado em feiras literárias, seminários, cursos, além de citado em artigos e publicações acadêmicas diversas. Em 2013, a autora foi homenageada no IV Latinidades: Festival da Mulher AfroLatino-americana e Caribenha, ocorrido em Brasília, quando também foi palestrante na mesa intitulada "Literatura Negra - nossas letras e vozes". Em 2015, foi vencedora do prêmio Jabuti, organizado pela Câmara Brasileira do Livro, com o livro Olhos D'água, lançado no mesmo ano.

A publicação de Ponciá Vicêncio (2003) representa a maior aceitação crítica de Evaristo, com traduções do português para diversos idiomas. O romance também é objeto de apreço no âmbito acadêmico, com números significativos de dissertações e teses a seu respeito, perpassando temas quase sempre relacionados à memória, identidade e resistência. A recepção calorosa da obra, de acordo com a autora, se dá pela identificação dos leitores com a protagonista:

Porque Ponciá Vicêncio agrada brancos, pretos, homens, mulheres? Porque ela (a personagem-título) traz a solidão humana. A solidão não é da minha propriedade, é de propriedade do ser humano. Acho que todo mundo se encontra naquela personagem pela solidão dela. A solidão dela é que chama!(EVARISTO, 2017).

O narrador em Ponciá Vicêncio apresenta ao leitor a solidão exposta da personagemtítulo. Seus silêncios aparecem como resgate e arquivos de memória. É através do ato de

\footnotetext{
${ }^{5}$ Schwarse Prosa, 1988 e Schwarze Poesie, 1993. 


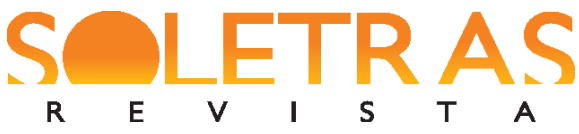

lembrar, numa busca incessante nas suas memórias, que Evaristo nos conta a história da personagem. Não havia perspectivas nem sonhos em Ponciá. Os seus dias eram feitos de lembranças e vazios.

Ao relacionarmos as adversidades sofridas por significativa parcela da população afrodescendente no Brasil, faz-se necessário ressaltar que, em contraposição às iniciativas de apagamento perpetradas por políticas de acobertamento dos traços de africanismos, surgem inúmeras e potentes iniciativas e expressões de resistência, erguidas com base na memória, na memória ancestral, na tradição e na oralidade. O fortalecimento do campo da literatura negrobrasileira, como categoria e conceito estético, identitário e autoral, pode ser boa ilustração da positividade de tais iniciativas. Refletindo sobre a ancestralidade como categoria analítica, nos permitimos interseccionar teóricos que, apoiados numa dita filosofia negro-africana, revelarão a relação entre ancestralidade, experiência negro-brasileira, memória e inventividade em seus trânsitos, articulações, negociações, agenciamentos e fluxos, que contribuem pata a existência das dinâmicas deformação e de transformação da experiência negro-brasileira

\section{Silêncio, memória e ancestralidade em Ponciá Vicêncio}

No romance Ponciá Vicêncio, a ancestralidade e a memória são os fios condutores de uma narrativa que nos impulsiona a acompanhar a reescritura identitária de uma mulher negra. Em seu exercício de lembrar, a personagem-título convida o leitor a traçar com ela as linhas que conectam o seu passado ao seu presente. Através dos retalhos de memória da protagonista, o narrador nos leva a uma viagem na qual o tempo é o trilho aonde descarrilham as vivências de Ponciá. Remetemo-nos ao tempo, tendo como perspectiva o tempo que não pode ser quantificado; um outro tempo e espaço, de memórias e lugares ancestrais, guardados na experiência da diáspora negra, o tempo mítico africano, tal qual o narrador evidencia através das impressões da mãe da personagem em um dado momento da história:

A mãe de Ponciá e de Luandi ainda esperou por alguns segundos que a velha esboçasse qualquer outro desejo de gesto. Entretanto, naquele momento, por um instante, o mundo inteiro pareceu se quedar. Nengua Kainda adormecera. Um sol quente batia em sua pele negra enrugada pelas dobras dos séculos. Em silêncio, ela adentrava num sono tão profundo do qual só acordaria quando tivesse ultrapassado os limites de um outro tempo, de um outro espaço e se presentificasse ainda mais velha e mais sábia, em um outro lugar qualquer (EVARISTO, 2003, p.115). 
Ao apresentar a experiência da morte na visão dos povos banto e nagô através de uma personagem emblemática, como Nengua Kainda (o arauto da comunidade na qual Ponciá Vicêncio cresceu), pensamos na passagem da vida como um rito.

Estaria o narrador nos falando do tempo conforme conhecemos na cultura ocidental? Que lugar seria este em que Nengua Kainda renasceria mais velha e mais sábia? O tempo mítico em que a narrativa é construída é o tempo cíclico, não linear, não histórico, no qual os povos africanos acreditavam antes do contato com a cultura europeia. Para esses povos, nada é novidade, tudo se repete desde os tempos imemoriais. Por esse motivo, a sacerdotisa não reconhece a morte nos padrões ocidentais, mas sim, no tempo espiralado. É por isso que Nengua Kainda se presentifica mais velha e mais sábia em outro espaço.

Juana Elbein dos Santos lembra que na cultura dos povos nagô, "a morte não significa a extinção total, ou aniquilamento, conceitos que verdadeiramente aterram" (SANTOS, 1986, p. 221). Morrer, ainda segundo a autora, "é uma mudança de estado, de plano de existência e de status" (Idem). São os acontecimentos do passado que sobrevivem na perspectiva dos mitos:

É no tempo mítico do passado remoto que se acredita estar a verdade do presente. O tempo do mito é o tempo das origens. O passado mítico, coletivo, compartilhado de geração a geração, fornece à sociedade o sentido geral da vida, orienta a conduta e fornece valores para nortear a vida. $\mathrm{O}$ tempo do mito é, portanto, o tempo da tradição, da permanência, da ancestralidade (PRANDI, 2005, p. 168-169).

É nesse tempo não linear, não-cronológico, que se insere o ato de rememorar da personagem. Em sua rotina, ela "[...] gastava todo o tempo com o pensar, com o recordar. Relembrava a vida passada, pensava no presente, mas não sonhava e nem inventava nada para o futuro. O amanhã de Ponciá era feito de esquecimento" (EVARISTO, 2003, p. 19). E, complementamos, de lembranças. Essas lembranças representam um calabouço, uma antítese, carregam uma dupla função: a de garantir que a personagem não se esqueça de suas origens e de permitir que ela se confronte com sua identidade, fazendo da memória um elo entre o seu passado e a sua identificação no e com o mundo: 


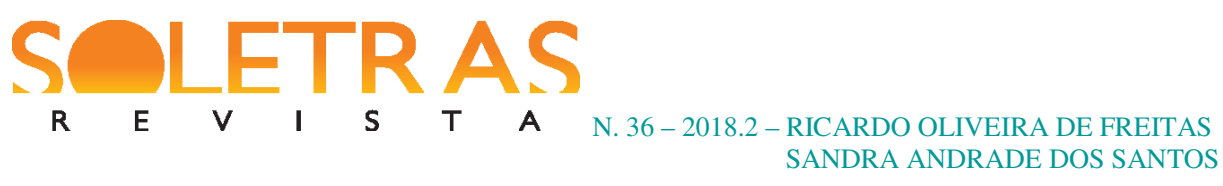

A coersão da memória pesa definitivamente sobre o indivíduo, como sua revitalização possível repousa sobre sua relação pessoal com seu próprio passado. A atomização de uma memória geral em memória privada dá á lei da lembrança um intenso poder de coersão interior. Ela obriga a cada um a se relembrar e a reencontrar o pertencimento, principio e segredo da identidade" (NORA, 1993, p. 18).

Desde que fizera a partida, num tipo de diáspora, saindo da comunidade quilombola para viver na cidade grande, coube à Ponciá assumir a responsabilidade sobre suas escolhas e sobre sucessivas perdas. A migração do campo para a cidade representa a história de muitos homens e mulheres negras que buscam, na cidade grande, realizar o sonho de nova vida, fugindo da realidade de servidão reservada aos seus iguais.

Ao longo dos anos, a vida de mulher, negra, pobre e semianalfabeta se presentificou com todas as suas agruras para a personagem. Restou-lhe um quartinho na periferia, um casamento fadado à violência doméstica, a cruel lembrança dos sete filhos que não "vingaram" e uma profunda melancolia.

Quando mais nova, a menina sonhara com outro nome para si, afinal não era capaz de se reconhecer no nome que carregava, fruto da herança do senhor das terras que em que vivia, o coronel Vicêncio. O seu sobrenome era uma ferida, uma queimadura no seu corpo de mulher negra, não lhe pertencia. À frente do espelho, a mulher chama por outro nome em busca de reconhecimento, mas a angústia permanece. Vicêncio representa, em suas memórias, a herança da escravidão. Era preciso um novo nome que lhe coubesse, uma nova história.

A solidão da personagem grita em todas as páginas do romance, seja no quartinho do barraco que divide com o marido, seja na casa da patroa, seja na busca solitária por um novo nome. $\mathrm{O}$ fato é que a vida presente de Ponciá não lhe faz sentido. A personagem busca, então, através do silêncio e do vazio, ressignificar o tempo presente:

Ponciá Vicêncio não queria mais nada com a vida que lhe era apresentada. Ficava olhando sempre um outro lugar de outras vivências. Pouco se dava se fazia sol ou se chovia. Quem era ela? Não sabia dizer. Ficava feliz e ansiosa pelos momentos de sua auto-ausência. Antes gostava de ler (EVARISTO, 2003, p.90).

Apartar-se do presente é a forma que a personagem encontra para dizer que o lugar onde está inserida não tem significado para ela. O sistema social em que Ponciá vive (e é retratado no texto) a proíbe de ter uma vida digna e decente. Como ser completa e feliz no 


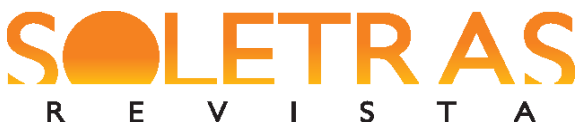

cômodo empoeirado e sujo onde morava, com a comida escassa servida na lata de goiabada vazia? A realidade dela não cabia em seus sonhos. Por esse motivo, a volta à infância era sempre um modo de tornar-se outra vez completa.

Eni Orlandi apresenta a perspectiva do silêncio como fonte para compreender a incompletude do sujeito:

A incompletude é uma propriedade do sujeito (e do sentido), e o desejo de completude é que permite, ao mesmo tempo, o sentimento de identidade, assim como, paralelamente, o efeito de literalidade (unidade) no domínio do sentido: o sujeito se lança no seu sentido (paradoxalmente universal), o que lhe dá um sentimento de que esse sentido é uno(ORLANDI, 2007, p. 78).

O sentimento de unidade que permitiria a Ponciá identificar-se está em outro tempo e em outro território, está no tempo das suas memórias. E essa incompletude, que a acompanha desde sempre, é o resultado do movimento da personagem entre as diferentes formas de sentido da própria vida, da felicidade pueril vivida na comunidade quilombola em companhia de sua família. É parte da realidade da diáspora, da vida na favela. Tal qual propõe Eduardo Oliveira, Ponciá Vicêncio transcende através da imanência. "Não porque metafísica, mas porque, como a metalinguagem, dá sentido aos sentidos que produzimos" (OLIVEIRA, 2007, p. 62).

O silêncio em Ponciá é, pois, uma percepção de espaços internos e externos, marcado pelo lugar que é destinado à mulher negra na sociedade ocidental: lugar de margens, de violência, de fome e de miséria. Portanto, ao apartar-se do tempo presente, a personagem retoma um lugar de resistência.

O vazio em Ponciá é proposital e não pode ser considerado como uma ausência, simplesmente. Ele exige outra possibilidade, outra experiência. O silêncio da personagem é a sua força. Segundo Eni Orlandi, "as palavras são múltiplas, mas os silêncios também o são" (ORLANDI, 2007, p. 28). Ao pensar o silêncio através de sua dimensão política, verifica-se que esse pode ser considerado tanto através da retórica da dominação, apoiado em seu caráter opressor, como através da sua contrapartida, a retórica do oprimido (ou da resistência). A nós, interessa pensar o silêncio através dessa última dimensão, tal qual a pesquisadora propõe: o silêncio como o real do discurso, para além das categorias binárias, o silêncio como o "fundante do discurso". Ou seja, o silêncio não como falta, mas como linguagem, como 


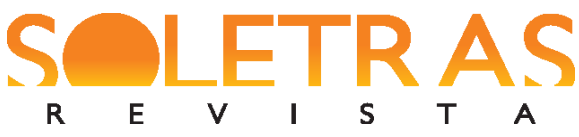

excesso: "O silêncio não fala. O silêncio é. Ele significa. Ou melhor: no silêncio, o sentido é" (ORLANDI, 2007, p. 31).

Ponciá Vicêncio é essa personagem que pouco fala, mas o seu corpo está em constante performance. Lembrar, esquecer, escamotear-se no vazio são as formas que a protagonista encontra para conversar com o seu leitor. Atravessamos a parede da profunda solidão de Ponciá para sermos arrebatados pelas suas memórias, traduzidas no campo simbólico do silêncio. Na perspectiva da filosofia da ancestralidade africana, segundo Eduardo Oliveira (2007), o silêncio é pai de toda palavra. É o que verdadeiramente unifica a experiência, já que dá densidade aos seres, dá o peso da existência, atribui afirmação ao ser. Em Ponciá, a personagem, o silêncio e o vazio expostos na carne e na alma funcionam como retenções de forças, abrigos para quem sabe que aquele tempo presente não merece sequer um gasto de energia. É como se Ponciá sempre soubesse o momento em que seu corpo tomaria novamente as rédeas de sua vida:

Ponciá gastava a vida em recordar a vida. Era também uma forma de viver. Às vezes, era um recordar feito de tão dolorosas, de tão amargas lembranças que lágrimas corriam sobre o seu rosto; outras vezes, eram tão doces, tão amenas as recordações que, de seus lábios surgiam sorrisos e risos. Tanto tempo já tinha se passado. Quando se encontrariam juntos os três? Parte de sua vida era o desejo que isso acontecesse. Porém, nada fazia, a não ser ficar ali, calma, sentada, quase inerte. Era preciso esperar. E era isso que ela estava fazendo há anos. Fazia o que as suas forças lhe permitiam. Só lhe era possível esperar (EVARISTO, 2003, p.92).

O que espera Ponciá? O desejo que permeia a maior parte da narrativa provém do reencontro com sua mãe e seu irmão Luandi. Mas, por qual motivo ela não resolve correr o mundo em busca desse encontro? Tal qual a ideia de tempo mítico, a expectativa da personagem, em um determinado momento, perceber-se pronta. E, para estar pronta, é necessário esperar. Nesse sentido, Ponciá não calava em vão. Ela esperava no silêncio. Antes, em suas memórias, negava a realidade em que vivia, o nome pelo qual não se reconhecia, o barraco-flagelo em que morava, o relacionamento com o marido.

Ainda, segundo Eni Orlandi, "quando não falamos, não estamos apenas mudos, estamos em silêncio, existe nele um pensamento, uma introspecção" (ORLANDI, 2007, p. 35). O silêncio não é transparente, ele é tão ambíguo quanto às palavras, pois se produz em 
condições específicas que vão constituir o seu modo de significar. Em Ponciá Vicêncio, o silêncio é um arcabouço de memórias subterrâneas. Ele não é distanciamento, mas presença.

As memórias da protagonista funcionam, assim, como um modo de sobrevivência:

Essas lembranças durante tanto tempo confinadas ao silêncio e transmitidas de uma geração a outra oralmente, e não através de publicações, permanecem vivas. $\mathrm{O}$ longo silêncio sobre o passado, longe de conduzir ao esquecimento, é a resistência que uma sociedade civil opõe ao excesso de discursos oficiais. (POLLAK, 1989, p. 5).

Eclea Bosi afirma que é na velhice que a lembrança desempenha sua alta função, já que, nesse momento, os interesses são deslocados, a nitidez e as imagens de outrora crescem, a ação de relembrar exige um espírito desperto e gera "a capacidade de não confundir a vida atual com a que passou, de reconhecer as lembranças e opô-las às imagens de agora" (BOSI, 1994, p. 39). Em Ponciá Vicêncio, a protagonista comunga de um sentimento corriqueiro entre idosos: o de opor o presente às lembranças do passado. É apenas no passado que ela carrega as memórias afetivas.

O amor, por sua vez, é narrado através das lembranças com a mãe, no trabalho com o barro, na presença silenciosa do pai e do irmão. Essas relações de amor em família contrastam com a solidão de Ponciá e de seu homem, ambos marcados pela miséria. O homem de Ponciá busca através de socos e pontapés trazê-la de volta à realidade. Ela, por sua vez, não apenas o teme, mas se resigna, se endurece, se cala. A personagem segue a sina reservada à boa parte das mulheres em sua condição de pobreza.

Não lhe foi dada a possibilidade de ser mãe. Nenhum dos seus sete filhos vingou. Uma ausência atravessa a solidão dos dois, da mulher e do homem. Uma solidão tão perceptível, que seu homem, ao entender a sua solidão e compará-la com a solidão da sua companheira, vê na mulher o seu semelhante, sendo tomado por uma ternura intensa por ela. O homem de Ponciá passa, então, a compreendê-la melhor:

A saudade que ela dizia sentir do pai e dos avôs mortos, da mãe e do irmão desaparecido. Ela, às vezes, dizia também que tinha saudade do barro e, de tempo em tempo, apresentava um incômodo entre os dedos que coçava até sangrar (EVARISTO, 2003, p. 109). 
Ao apresentar a memória de seus antepassados, Ponciá é atravessada pela ancestralidade que, antes de tudo, é sua herança.

As suas lembranças começam através da recordação do primeiro homem que conhecera em sua família, o Vô Vicêncio. Mesmo pequena, dele guardava todas as feições. Ponciá reteve na memória os choros e risos do seu avô e com ele era pura parecença, "como ainda as feições do velho que se faziam reconhecer no semblante jovem da moça" (EVARISTO, 2003, p. 63). No dia em que aprendera a andar, a menina que se recusara a engatinhar, desce do colo da mãe e, para total surpresa e espanto de todos, reproduz a forma de andar do Vô Vicêncio, como mostra o trecho a seguir:

\begin{abstract}
Andava com um dos braços escondido às costas e tinha a mãozinha fechada como se fosse cotó. Fazia quase um ano que Vô Vicêncio tinha morrido. Todos deram de perguntar por que ela andava assim. Quando o avô morreu, a menina era tão pequena! Como agora imitava o avô? Todos se assustavam. A mãe e a madrinha benziam-se quando olhavam para Ponciá Vicêncio. Só o pai aceitava. Só ele não espantou ao ver o braço quase cotó da menina. Só ele tomou como natural a parecença dela com o pai dele. (EVARISTO, 2003, p.16).
\end{abstract}

Esse é o primeiro sintoma da narrativa que apresenta o corpo-negro brasileiro talhado pelos mitos de matrizes africanas, através do desenho de Ponciá menina. É um corpo em plena performance de memória, relacionado com o seu território, com a sua ancestralidade, com a sua família e que não se delimita às razões eurocêntricas. Para Leda Martins (2003), o corpo na performance é local de inscrição de conhecimento que se grafa no gesto, no movimento, na coreografia, na superfície da pele, assim como os ritmos e timbres da comunidade.Para a autora, o corpo é local de inscrição da ancestralidade, pois "nas culturas predominantemente orais e gestuais, como as africanas e as indígenas, por exemplo, o corpo é, por excelência, o local da memória, corpo em performance, o corpo que é performance" (MARTINS, 2003, p.78).

A performance do corpo não remete apenas à dupla-repetição de uma ação, mas constitui, em si mesma, a própria ação. Partindo desse pressuposto, ao reproduzir os trejeitos do avô, com todas as características ancestrais de um Preto-Velho, Ponciá menina imprime nas costas curvadas, nos gestos das mãos, os arabescos para que possamos evidenciar esse corpo como um rastro de memória, local de saber contínuo das tradições negro-africanas. 


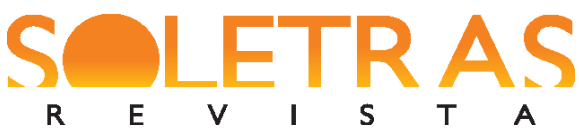

Como explicar o fato de a menina ter tantas parecenças no andar, nos gestos, nas feições com o avô? A partir desse relato, o narrador instaura para o leitor uma possibilidade de reflexão. Aqui, a categoria memória é intrinsecamente disposta com a ancestralidade para traçar o caminho da construção identitária de Ponciá Vicêncio; como se, de algum modo, pudéssemos responder às questões tão simbólicas no trato da personagem e na sua construção como ser humano através da subjetividade. Como bem propõe Juana Elbein dos Santos:

O ser humano, como todos os seres, é constituído por elementos coletivos, representações deslocadas das entidades genitoras, míticas ou divinas e ancestrais ou antepassados (de linhagem ou família) e por uma combinação de elementos que constituem sua especificidade, ou seja, sua unidade individual (SANTOS, 1986, p. 203).

Não poderíamos analisara constituição identitária em Ponciá Vicêncio de modo isolado. Sabemos que toda identidade individual passa por experiências e relaciona-se com os modos de uma identidade coletiva. Portanto, propor a análise da categoria ancestralidade como fator constitutivo da identidade dessa personagem é também pensar a ancestralidade na cultura negro-brasileira, na sua coletividade regulada pelo sistema de trocas. O homem ou a mulher negra que experimenta a vivência nas comunidades de matrizes africanas, que experimenta a vida a partir do processo de iniciação dessas religiões, inscreve-se numa ordem metafísica, revela uma nova identidade de si, passa a conhecer as relações entre os vivos e os mortos, o real e o sagrado. Nesse sentido, pensar a ancestralidade negro-brasileira é refletir, sobretudo, sobre a forma como a cultura negro-brasileira talha a existência de uma religiosidade negro-brasileira, que nos permite dialogar com as formas com que o homem e a mulher negra vivenciam essa experiência.

Muniz Sodré afirma que a cultura negro-brasileira difere da cultura ocidental por não estar baseada no excedente econômico social do acúmulo. Na cultura negra, a troca não é dominada pela acumulação, "por que é sempre simbólica e, portanto, reversível: a obrigação (de dar) e a reciprocidade (receber e restituir) são as regras básicas" (SODRÉ, 1988, p. 127). Nenhum ser vivo é excluído do processo de troca nos ciclos vitais: bichos, plantas, minerais, homens vivos e homens mortos. Para as culturas ocidentais, essa troca é chamada de animismo, pois a vida é separada da morte e as trocas simbólicas existentes na cultura negra 


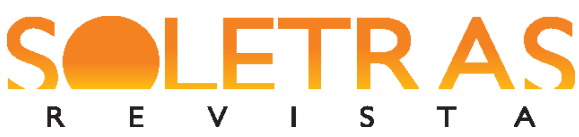

seriam uma projeção fantasiosa da vida. Para o povo negro, a vida (aiê) e a morte (orun) não se opõem, não se excluem radicalmente, já que estão em constante trânsito:

O ancestral (morto), pai ou mãe, está sempre presente no grupo como um aliado, parceiro essencial da troca: ele é dado e recebido pelo vivo no ritual da iniciação, ela dá a terra (donde vem a alimentação), que é simbolicamente restituída através do sacrifício (SODRÉ, 1988, p. 128).

A iniciação, nesse caso, é vista como um processo complexo de entrada do indivíduo no ciclo das trocas simbólicas e, através dela, são resolvidas e exterminadas "as grandes dicotomias que engendram o princípio da realidade do Ocidente (morto/vivo, real/irreal, natural/humano, abstrato/concreto, etc.)" (SODRÉ, 1988, p. 128).

Os conhecimentos advindos da iniciação passam pelo corpo e dependem do contato concreto dos indivíduos, através do qual o axé é transmitido. Os bantos também têm o axé como princípio essencial, mas designado pela palavra muntu. O muntu vai partir do mesmo princípio do axé, existindo nos seres humanos (vivos e mortos) e "sendo força, mantém-se, cresce, diminui, transmite-se em função da relação (ontológica) do indivíduo com os princípios cósmicos (orixás), com os irmãos de linhagem, com os ancestrais, com os descendentes" (SODRÉ, 1988, p. 129).

Para tomarmos a cultura nagô como categoria de análise em Ponciá, devemos considerar, na estrutura do texto, a relação de Ponciá com o barro, que, por sua vez, pode ser relacionado às diversas formas em que a morte se liga, ao longo do texto, à história de vida da personagem. Na mitologia das religiões de matrizes africanas brasileiras, a lama ou o barro é a matéria prima utilizada pelo orixá Obatalá, deus na criação do ser humano. É,também, o elemento destacado e representado na orixá Nanã Buruku, que, junto com seus dois filhos míticos, Obaluaiê e Oxumaré, compõe o conjunto de orixás responsáveis pelo ciclo do renascimento, do poder e do mistério das entranhas da terra.

Nanã é a representação da lama e da morte. O emblema de Nanãé olbiri, que caracteriza sua relação com os espíritos ancestrais. À Nanã é dado o poder genitor, no qual os mistérios do renascimento se processam nas suas entranhas. Para conceber a vida, precisa ser ressarcida constantemente. Ela é a orixá que recebe os mortos e que tornará possível o renascimento. Em Ponciá Vicêncio, o barro é a energia vital que alimenta a personagem na infância e é através do barro que Ponciá sente a necessidade de reencontro com o seu povo. É 
através do barro que Ponciá constrói laços de afetividade com seus familiares e com a sua casa. Naquele espaço, todos os elementos eram feitos da terra e modelados por ela e pela sua mãe.

Dejair Dionísio (2013), ao apresentar em sua pesquisa a perspectiva da ancestralidade banto em Ponciá Vicêncio, chama a atenção para a aproximação das práticas ancestrais dos povos congoleses com o caminho traçado por Ponciá na narrativa. O autor propõe uma proximidade entre a tradição que os povos do Congo têm de confeccionar esculturas de argila, numa referência aos seus antepassados, à experiência de Ponciá no trato com o barro, com a saudade que ela sentia de modelar a vida através de seus dedos, simbolizando a relação intrínseca com o elemento vital para os povos banto.

Para o autor, a saudade que Ponciá sentia do trabalho com o barro pode ser entendida como a saudade da sua ancestralidade, o que ilustra a "[...] ligação que as personagens têm com o barro e dão-nos a dimensão da memória coletiva e pode estar ligada à mesma memória dos congoleses e suas proximidades com a ancestralidade, contida nesses trabalhos" (DIONISIO, 2013, p. 75). Lembremos que Ponciá tinha uma necessidade especial de mexer com o barro. Um desejo tão latente, que, como vimos, coçava as suas mãos e sangrava os seus dedos:

Correu lá no fundo da casa, no seu quarto de empregada, e tirou o homembarro de dentro da trouxa. Cheirou o trabalho, era o mesmo odor da mão. Ah! Então era isso! Era o Vô Vicêncio que tinha deixado aquele cheiro. Era de Vô Vicêncio aquele odor de barro! O homem chorava e ria. Ela beijou respeitosamente a estátua sentindo uma palpável saudade do barro. Ficou uns instantes trabalhando a massa imaginária nas mãos. Ouviu murmúrios, lamentos e risos... Era Vô Vicêncio. Apurou os ouvidos e respirou fundo. Não, ela não tinha perdido o contato com os mortos. E era sinal de que encontraria a mãe e o irmão vivos. (EVARISTO, 2003, p. 75).

\section{Saída}

Eduardo Oliveira (2007) lembra que a ancestralidade é um tecido produzido no tear africano, no qual labirintos se abrem nas esteiras do tempo, desdobrando-se nos corredores das memórias. Ponciá Vicêncio se revelou, para nós, configuração do real, do vivido e experimentado nos becos das nossas memórias, da mesma maneira que Conceição Evaristo ficcionalizou as suas lembranças para que pudéssemos, hoje, fazer delas objetos de análise. 


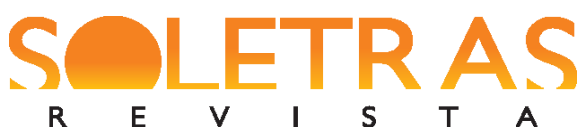

Através da análise de Ponciá Vicêncio, entendemos que as categorias memória e ancestralidade surgem como alicerces necessários para a construção da subjetividade negrabrasileira. Ao elaborar tal proposição, fez-se importante conceituar a ancestralidade, que é, por sua vez, essencialmente ligada ao fenômeno da cultura e da sua dinâmica, pois, de qual maneira, senão através dos costumes criados e recriados em solo brasileiro, poderíamos conceituar ancestralidade e modos de ser negro-brasileiros? O tempo da ancestralidade é o tempo que se renova, é cíclico, não linear, como propôs Leda Martins (2003). É o tempo crivado de identidades e, em cada uma de suas dobras, abriga-se um número de identidades flutuantes (OLIVEIRA, 2007).

No processo de descoberta de uma literatura uterina, com a voz potente da mãe-preta a "acordar os da casa-grande de seus sonos injustos" (EVARISTO, 2007, p. 21), sustentamos a ideia de que a literatura negra feminina de Conceição Evaristo é alicerçada por uma série de outras, não menos importantes, autoras negras, que, hoje, despontam no cenário literário brasileiro, buscando afirmar em suas obras a importância do caráter poético e ancestral do e no texto de autores e autoras negras brasileiras.

E como um baobá, como uma grande árvore da vida, fonte de fertilidade, com suas raízes potentes fincadas em solo sagrado, acreditamos que a representatividade concedida a Conceição Evaristo na atualidade seja o início de uma série de consagrações de autoras negras que se destacam e desafiam o silenciamento imposto pelo mercado editorial ou, mais objetivamente, pelas forças hegemônicas da sociedade brasileira. Através da escrevivência, Conceição Evaristo reafirma seu papel e lugar junto às mulheres e às escritoras negras.

Em Ponciá Vicêncio (2003), a ancestralidade e memória se entrelaçam às representações da religiosidade negro-brasileira através do silêncio, que, nesse texto, foi considerado como potência de resistência na personagem. Constatamos, dessa forma, que o silêncio pode ser como um grande segredo iniciático, no qual, apenas através dos rituais, os iniciados são convidados a compartilhar da força ativa, do axé.

Oxumarê, Nanã e Obaluayê compõem a tríade do tempo que concede a Ponciá a força necessária para, no tempo da espera, tolerar as agruras da singela vida preenchida de vazios. A ancestralidade, desse modo, se traveste de um caráter político. A memória, aqui apresentada, é a possibilidade de mudança da história dos descendentes de escravizados e 


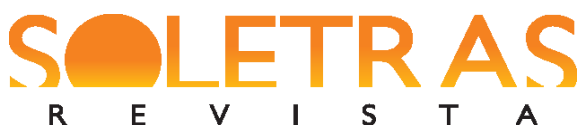

escravizadas, através da proposta da personagem, da reinscrição das dores dos escravizados e das escravizadas, das dores que também são dela, modificando a história de seu povo.

Ao refletirmos sobre a ancestralidade e a memória, percebemos a importância que o território possui para a constituição da história dos povos e da cultura tradicional africana e negra-brasileira. O corpo conectado com sua terra e com sua família seria, sem esses dois elos, apartado de sua ancestralidade. É como se, a todo momento, fôssemos puxados para dentro da subjetividade da personagem analisada.

A ligação fraterna que conduz à representação dos orixás Oxumarê, Nanã e Obaluayê nas suas passagens pela história nos remete à relação desse orixá com o ventre restituído do orixá Nanã, este último, ligado ao cordão umbilical e à placenta, ligando, portanto, os destinos familiares em Ponciá Vicêncio.

Para Ponciá, reencontrar os seus, assumir sua herança, era como restabelecer o ciclo da vida quebrado pelo Vô Vicêncio. Era ela a verdadeira herdeira de uma história sofrida, contida, não na sua experiência individual, mas na vida e memória coletiva de seu povo.

Sob os olhos do seu irmão Luandi, a vida, ao observar o encontro da irmã com seu destino, apresentava-se como um "[...] tempo misturado do antes-agora-depois-e-do-depoisainda." (EVARISTO, 2003, p. 127). A vida era uma mistura de todos e de tudo. Dos que foram, dos que estavam e dos que viriam a ser. Enquanto isso se diluía, nas margens, a grande cobra colorida, o elo que ligava o passado e o presente.

Em Ponciá, “[...] a herança de uma memória reencontrada pelos seus [...]." (EVARISTO, 2003, p. 128), que não se perderia, estaria guardada nas águas do rio, na ancestralidade que atravessa a vida e reafirma a sua identidade de mulher negra.

Desse modo, concluímos, baseados na análise do romance Ponciá Vicêncio, que a literatura de Conceição Evaristo funciona com importante ferramenta tanto para promover um tipo de literatura que fortalece a comunidade, que marca seu lugar de fala (termo tão em voga nos últimos tempos) como escritora, como mulher, como mulher negra, periférica, que age sobre a sua subjetividade, mas, que também age sobre a identidade da comunidade, da sua comunidade, de mulheres, de negros, de periféricos, de leitores. Um tipo de literatura que muito se aproxima das expressões em arte e manifestações culturais que têm servido ao ativismo social, num tipo de ativismo, que, mesmo quando está à margem do sistema, à margem do mercado (editorial, por exemplo), que mesmo quando nega as histórias oficiais da 


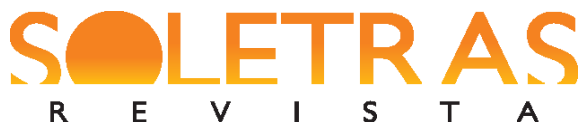

cultura, tem poder crítico e, por isso, interpela, não somente a comunidade, mas também, as culturas hegemônicas, as culturas centrais, num tipo de produção crítica, de enfretamento, naquilo que Heloísa Buarque de Hollanda cunhou, na primeira década dos anos 2000, como sendo fruto das "novas periferias literárias" que "vêm se redefinindo em função das lógicas dos processos de globalização neoliberal" e provocando importantes "enfretamentos culturais ao contexto político e econômico do século XXI", ou seja, a "literatura e a cultura produzida na periferia das grandes cidades brasileiras e seu poder de interpelação e impacto na produção canônica e de massa" (HOLLANDA, 2017).

\section{Referências}

BOSI, Ecléa. Memória e sociedade: lembranças dos velhos. 3. ed. São Paulo: Companhia das Letras, 1994.

COSER, Stelamaris. Circuitos transnacionais, entrelaçamentos diaspóricos. In: DUARTE, Constância Lima; CÔRTES, Cristiane; PEREIRA, Maria do Rosário. Escrevivências: identidade, gênero e violência na obra de Conceição Evaristo. Belo Horizonte: Editora Idea, 2015.

DIONÍSIO, Dejair. A ancestralidade bantu na Literatura afro-brasileira: reflexões sobre o romance Ponciá Vicêncio, de Conceição Evaristo. Belo Horizonte: Editora Nandyala, 2013.

EVARISTO, Conceição. Ponciá Vicêncio. Belo Horizonte: Mazza Edições, 2003.

Da grafia-desenho de minha mãe um dos lugares de nascimento de minha escrita. In.: ALEXANDRE, Marcos Antônio (Org). Representações Performáticas Brasileiras: teórias, práticas e suas interfaces. Belo Horizonte, Mazza Edições, 2007, p 16-21.

. Conceição Evaristo: a literatura como arte da "escrevivência". 11 jul. 2016. Jornal O Globo. Entrevista concedida a Leonardo Cazes. Disponível em: <https:// oglobo.globo.com/cultura/livros/conceicao-evaristo-literatura-como-arte-da-escrevivencia-19 682928 >. Acesso em: 05 out. 2016.

Literatura potente de Conceição Evaristo é tema de mesa da FliCaixa. 29 abr. 2017.

Jornal Correio. Entrevista concedida a Marília Moreira. Disponível em: http://www.correio24horas.com.br/noticia/nid/literatura-potente-de-conceicao-evaristo-etema-de-mesa-da-flicaixa/. Acesso em: 18 set. 2017.

HOLLANDA, Heloísa Buarque. Literatura marginal. Disponível em: http://www.heloisabuarquedehollanda.com.br/literatura-marginal/. Acesso em: 10 de janeiro de 2017. 


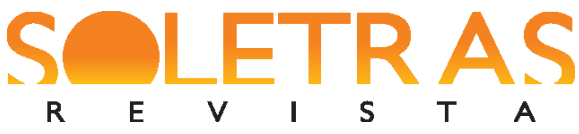

MACHADO, Adilbênia Freire. Ancestralidade e encantamento como inspirações formativas: filosofia africana mediando a história e cultura africana e afro-brasileira. 2014. 240f. Dissertação (Mestrado em Educação) - Universidade Federal da Bahia. Salvador, 2014.

MARTINS, Leda. Performances da Oralitura: corpo, lugar da memória. Revista Letras, Universidade Federal de Santa Maria, n.26, jun. 2003, p. 63-81.

NORA, Pierre. Entre história e memória: a problemática dos lugares. Revista Projeto História, São Paulo, PUC, v. 10, n. 10, dez. 1993.

OLIVEIRA, Eduardo D. Cosmovisão africana no Brasil: elementos para uma filosofia afrodescendente. Curitiba: Gráfica e Editora Popular, 2007.

ORLANDI, Eni Puccinelli. As formas do silêncio: no movimento dos sentidos. 6.ed. Campinas, SP: Editora Unicamp, 2007.

POLLAK, Michael. Memória, esquecimento, silêncio. Estudos Históricos, Rio de Janeiro, v. 2, n.3, 1989.

PRANDI, Reginaldo. Segredos guardados: Orixás na alma brasileira. São Paulo: Companhia das Letras, 2005.

SANTOS, Juana Elbein dos. Os Nagô e a morte: pàde, àsèsè e o culto Egun na Bahia. Petrópolis, RJ: Vozes, 1986.

SODRÉ, Muniz. A verdade seduzida: por um conceito de cultura no Brasil. 2.ed. Rio de Janeiro: Francisco Alves, 1988.

\section{Black-Brazilian ancestry in the novel Ponciá Vicêncio, by Conceição Evaristo}

Abstract: We investigate the way in which Black-Brazilian ancestry will be constituted as a constitutive element in Conceição Evaristo's narrative, through the analysis of her novel Ponciá Vicêncio (2003). Recognizing the author's literary density, we explore the construction of the character on Ponciá Vicêncio, presenting elements that identify what we defend as traces of ancestry present in the work. We relate these elements to the categories of memory and silence. Supported by the novel Ponciá Vicencio, we analyzed the ways and means with which Conceição Evaristo, through the artifice of writing (the writing of daily life, the memory of her life and her people), reveals the experience of being a black woman in a postabolitionist society which uses as devices aspects of black-Brazilian ancestry and with great contribution of memory, of a black-Brazilian memory, without giving up the poetic character. Keywords: Black-Brazilian literature. Ancestry. Memory. Conceição Evaristo.

Recebido em: 15 de abril de 2018.

Aceito em: 10 de julho de 2018. 